\title{
Applications, Smart Phones and Value Assessment: Digital Information in Academic Studies
}

\author{
Garai Annaํ, Nádai Julianna ${ }^{1}$
}

\begin{abstract}
:
In our presentation we focus on ways of decision mechanism how university students can evaluate the authenticity of digital information. To have a deep insight we made questionnaires which are the most appropriate way to get a big amount of relevant information on the research focus, in a relatively economic form. It is an underresearched, unrevealed area and a key issue as we do not have a wide knowledge of value systems of mobile internet users, the relationship between phone and computer applications and learning processes. Present statistics and social science publications are mainly focused on the increasing number of technical communication devices, that of applications and frequency of checking websites, but no research is made on users' evaluation mechanism.

Based on our questionnaires completed by university students we try to answer questions like how can students decide on authenticity of digital information? How can they use it efficiently for their studies? Based on the results you have the opportunity to develop new teaching methods in academic education for the future.
\end{abstract}

\section{Introduction. The conflict}

Starting any research activity is mostly triggered by a conflict situation that needs interpretation, explanation and correction. In the last few years a merely new methodology of teacher and student communication has been formed as a new way of knowledge transfer. There were hardly and signs of changes to be recognized previously and students transformed into mobinauts (a person using mostly mobile-internet) all of a sudden (http://www.telefonguru.hu/hir/Uj_faj_eljenek_a mobinautak!_2013-3-7). The year 2010 seems to be a turning point as the crucial changes have occurred for the last 4 years.

The communication of the internet age is a widely researched area in many thematic aspects. Most publications and scientific articles involve research on descriptive linguistics, language sociology and language (Balázs 2005; Bódi 2004; Bucher et al. 2010; Herman-Chomsky 2002; Veszelszki 2012). Beside linguistics analyses there are plenty of statistics data available on the number of mobile phones and the frequency of downloading (http://nrc.hu/ismerjenmeg/magunkrol), but attitude and value judgment of users are not revealed in any research publications. As our research focuses on these underresarched approaches, our study is attempting to fill this gap as a novelty.

In the 21 st century we always have to face the power of technology which rules our lives and the civilization regards any communication and any contact via mobile technology as

${ }^{1}$ Associate Professor, Széchenyi István Egyetem, Department of International Communication, Győr, Hungary.

${ }^{1}$ Assistant Professor, Széchenyi István Egyetem, Department of International Communication, Győr, Hungary. 
a higher ranked activity. This statement is justified in a research made in 2013 (http://www.telefonguru.hu/hir/Uj faj eljenek a mobinautak! 2013-3-7) and also describes mobinauts with only positive characteristic features, such as high qualification, high status, under age of 30, open-minded to innovations, hardworking and so on .

Based on this idea the best students are those using mobile internet although teachers at universities can hardly see anyone focusing on the teachers' lectures instead of gazing their monitors of various gadgets (notebooks, tablets, smart phones) in front of them. The students are about to look for information on what is heard at the lectures right then. This way they can discuss all topics with anyone out of classroom which broadens the number of students present at any lectures. The question can be raised if it is an acceptable way of studying or not. The changes are so fast that this question cannot be answered from any behavior code of universities as no one has adapted to the new situation and no one recorded exactly how to react students at lessons browsing their latest high-technology appliances. The high speed of spreading new technologies makes different communicating societies unable to reflect the changes in time.

In the followings we want to give some hints and insight into our research process and give a structural overview.

\section{Questions raised before research}

Digital technology as a medium projects an extreme speed and extent of multiplication of human skills and abilities never seen before. Any amount of information is available anywhere, anytime. Devices are able to carry out tasks for humans that needed plenty of time and human resources before which were not available at all. After accelerating work and moving from one place to another, the speed of thinking has been accelerated to maximum which enables us to ignore time and space, what is more, they seem to have disappeared.

Is it really a 'winning much - losing some' situation? What are the advantages and disadvantages or rather dangers of the new situation for those seeking to learn or study something? In our digital age the specific character of knowledge transfer concerning form and quantity as well as content and quality occur as primary issues for university lecturers. That is why it is really important to do research into issues like how university students can decide about authenticity and relevance of information attained from digital applications? How can students select the most useful information items from the enormous amount of information in their studying process?

The ability to distinguish authentic and useless, misleading information is only one aspect of the issue of the present research. It is also necessary to be cautious about terms like 'information consumption' as normally you do not consume but rather enrich your knowledge by using the information available.

In the digital age all participants and elements of communication processes have to face a merely new situation. Originally, messages were formed in a four dimension space as these messages had their senders and recipients, books had their authors and readers. Although books are also parts of the four dimension world, texts appear in two dimensions. Electronic and digital surfaces provide also two dimensions where applications are generated, consumed and even shared. The hidden generator, consumer and sharer wear a mask and a new role behind the screens which also changes their behavior adapting them to a new situation. 
What are the most relevant differences between generators, senders and recipients of digital messages? Do they share any common characteristic features at all? We usually consider senders and recipients of messages to be autonomic, conscious and critical personalities, but are these characters also true of mobinauts generating, consuming and sharing application contents?

\section{Method of research}

To carry out research we used questionnaires to have a deeper insight into the university students' way of thinking, habits and value judgment regarding mobile applications. Based on the results of the questionnaires we are able to set clearly the necessary changes to teaching contents and methodology to be used in the quickly formed new digital environment at universities.

The theoretical hypotheses on the media consumption of students and digital information authenticity judgment are accepted or rejected in practice by using and analyzing self-completed questionnaires. Questionnaires are the most suitable form of getting information relatively fast about individual opinion and experience, and we could minimize costs of research, too. The economic structure of the questionnaire was created to get the biggest amount of information possible.

The method of questionnaires proved to be the best way for research as it could prevent us from any form of influencing the respondents in answering the questions (Horváth 2004). The context of a highly accelerated lifestyle of the responding students demanded a research method which did not require too much time from the respondents to contribute to carrying out our research, that is, completion of the questionnaires is not time consuming which can ensure us to get realistic answers.

The questionnaires include 27 close ended questions with 3 or 4 variables. The respondents are selected according to specific criteria: age, qualification level and interest which resulted in a relatively homogeneous group of respondents in terms of research.

The questionnaires were and are completed by students of the Széchenyi István University (Győr, Hungary) by first, second and third year BA/BSc students. The total number of respondents is 344, 214 women and 130 men aged between 18 and 24 years. The questionnaires were spread in printed form directly given to the students. This way we could be sure to get the completed questionnaires back in time for procession and evaluation.

To have proper results we decided to conduct our research in two phases. In the first phase the questionnaires were completed by a random selected group of 30 respondents so that we could see the points and questions that needed some changes to have clear and transparent answers. Conclusions of the testing phase will be described in this study, as well.

In the second phase of research we could formulate the final version of the questionnaires based on the consequences of the 30 test-questionnaires' results. Till this time 208 questionnaires have been completed by the students of Széchenyi University.

The questionnaires include 27 questions with the following variables:

27 questions with 6 variables

1) Technology used for attaining information: tablet, mobile phone (applications!), computer 
2) Authenticity of digital information resource

3) Frequency of searching for information by each device

4) Type of information: studying material, background information, dictionaries etc.

5) Practical application of attained information: studying, exams

6) Socio-cultural effects: human relationships, self-assessment

\section{Testing the questionnaire}

In the testing phase of the questionnaires questions 1-4 focus on the technology used for attaining information (tablet, mobile phone /applications!/, computer). Based on the answers we can see that computers have a leading role (51\%) in spite of spreading mobile devices like tablets and smart phones. Unfortunately this can be a misleading result about the preference of respondents and we cannot accept it definitely as most students in Hungary do not have an own salary, so the quality of technical devices are determined by their parents.

Questions 5-11 we intended to reveal what type of information the students find authentic and relevant for their studies. The results show that 43 percent of respondents are more likely to be willing to accept the information resources recommended by their fellow students rather than by their teachers.

The next 4 questions (12-15) asked about the frequency their students use their devices for finding required information compared to traditional printed materials like books and notes. 19 of the 30 respondents $(63 \%)$ are in favor of high technology every day (even several times a day). Questions 16-21 dealt with the practical applicability of attained information for the students' studies and exams and tried to find answer for questions like how much this information is real help in preparation for exams. It was interesting to see that mobile internet was considered real help in their studying processes $(61 \%)$ while 72 percent of respondents prefer printed materials for preparation for exams as they find it more reliable.

The closing questions (22-27) aimed at mapping the effects of using smart phones and tablets on quality and way of making socio-cultural relations. We also tried to find out how these devices can contribute to individual studying success of the respondents. 64 percent cannot find any relationship between using technology and making social connections and the results are similar with the relation of success and smart phones.

Based on the previous results we cannot conclude correctly as the testing phase of the questionnaires involved only 30 students. Nevertheless, the testing phase made it possible for us to make necessary amendments to make the final version of the questionnaires even more effective. This intention was possible by making a new logical order of questions and formulating them really clearly which can prevent us from getting incomplete questionnaires from the respondents and getting controversial answers and we can also reduce the number of questions unanswered. And finally, some examples for the changes we made based on the results of the testing phase.

In the test questionnaires the questions on the mostly used technical devices came before those on the type of information attained from them. It was reasonable to change this order of questions to make sure the respondents are aware of what digital technology related activities they are asked about. 
Another change was necessary to make to the answer variables. The category 'other' was offered in the test questionnaires but it proved more sensible to emit because processing and analyzing the answers was overcomplicated.

Due to controversial answers it was logical to restrict the number of answers to be marked. In the original (test) version of the questionnaires respondents had the option to choose more than one answers. This was problematic as some students gave completely controversial answers or they even marked all possibilities ignoring any controversy. The function of the indirect questions was to get reliable information on the respondents' attitudes and opinions, so we found it misleading to give the opportunity to the students to mark each variable (Héra-Ligeti 2006).

\section{Summary. Current state of research}

University students' value assessment, attitudes, the relationship between using mobile internet applications and learning processes are still a really underresearched area. Most statistics and social studies publications focus on the number of digital devices, applications and frequency of website visits, but the users' opinion and value assessment are not analysed. Our short study was written with the intention of initiation and although the completion process of our questionnaires is still in process, analysis of the given information will serve as the basis of a following detailed study. To do so we need to make the further necessary changes in the structure of questionnaires and we have to raise the number of respondents to get a more reliable picture of the tendencies of digital technology, value assessment and learning process.

\section{References}

Babbie, E. 2013. The Practice of Social Research. Wadsworth: Cengage Learning

Balázs G. 2005. Az új média új müfaja, az sms hír - nyelvészeti megközelítésben. Magyar Nyelvôr.

129. évf. 2.. 130-150.

Bódi Z. 2004. A világháló nyelve. Internetező̉e és internetes nyelvhasználat a magyar társadalomban. Budapest: Gondolat Kiadói Kör Kft.

Bucher, H.-J. - Gloning, Th. - Lehnen, K, (ed.) 2010. Neue Medien - Neue Formate. Ausdifferenzierung und Konvergenz in der Medienkommunikation. Frankfurt am Main, New York, Campus Verlag.

Héra G. - Ligeti Gy. 2006. Módszertan. A társadalmi jelenségek kutatása. Budapest: Osiris Kiadó

Herman E. S. - Chomsky, N. 2002. Manufacturing Consent: The Political Economy of the Media. New York: Pantheon

Horváth Gy. 2004. A kérdöives módszer. Budapest: Műszaki Könyvkiadó

Veszelszki Á. 2012. Netsøótár. Budapest: ELTE. Eötvös Kiadó

http://www.telefonguru.hu/hir/Uj faj eljenek a mobinautak! 2013-3-7

http://nrc.hu/ismerjenmeg/magunkrol

http://de.statista.com/statistik/publikation/14/app-monitor-deutschland/ 
